\title{
Unconventional methods for forming implanto-distractors
}

\author{
Niekonwencjonalne metody kształtowania \\ implanto-dystraktorów
}

\section{ZBIGNIEW MACHYNIA \\ GRZEGORZ SKRABALAK ANDRZEJ STWORA MARIA ZYBURA *}

\author{
DOI: $10.17814 /$ mechanik.2016.5-6.77 \\ Międzynarodowa Konferencja IMT 2016
}

The paper presents design process and manufacturing of the dental implants, which have been improved in terms of the materials that are used, as well as their shapes and thread profiles that are employed. In the result of optimization works the shape and dimensions of dental implant made of titanium have been determined. For the needs of optimization, the parameterized geometrical axisymmetric model (2D) and the associated computational model FEM provided for calculation of the value of the objective function were used. In result of these works the model of dental implant was derived. The paper presents also the manufacturing process of implant and example of designed elements. One of the methods applied is the additive manufacturing process of Selective Laser Melting (SLM).

KEYWORDS: implanto-distractors, FEM, numerical modelling, selective laser sintering/melting (SLS/SLM)

W artykule przedstawiono problem optymalizacji implanto-dystraktorów dla doboru odpowiedniego kształtu i wymiarów implantów wykonywanych ze stopów tytanu. W procesie optymalizacji wykorzystano numeryczny model obliczeniowy MES. Na podstawie wybranego przykładu przedstawiono proces wykonania wybranych w procesie modelowania elementów implantu metodą selektywnego spiekania laserowego SLS.

SŁOWA KLUCZOWE: implanto-dystraktor, model CAD, optymalizacja numeryczna, metoda SLS/SLM

Shape of the threads for typical applications and typical pairs of materials of similar mechanical properties does not need optimization. In these cases, metric threads provide even distribution of forces and tensions on both connected components. This situation is different in case of titanium based dental implants, which are mounted into bones. Due to significant differences in mechanical properties (strength, Young modulus) of pair of connecting materials, application of metric thread would lead to uneven and harmful distribution of tensions - especially in the cancellous bone, causing its destruction even, when relatively small loads are applied $[1,2]$. The problem of pairing titanium based implants with cancellous bone induced necessity of optimization of dental implant thread in order to minimize tensions causing cancellous bone destruction, under specific load, through proper tension distribution.

Properly designed dental implants were later on manufactured of titanium alloy using the Selective Laser Melting/Sintering technology (SLM/SLS).

\footnotetext{
* Mgr inż. Zbigniew Machynia (zbigniew.machynia@ios.krakow.pl), dr inż. Grzegorz Skrabalak (grzegorz.skrabalak@ios.krakow.pl), mgr inż. Andrzej Stwora (andrzej.stwora@ios.krakow.pl), dr Maria Zybura (maria.zybura@ios.krakow.pl) - Instytut Zaawansowanych Technologii Wytwarzania, ul. Wrocławska 37a, 30-011 Kraków
}

\section{FEM Analysis}

In order to develop the shape of the thread providing harmless interaction between dental implant and cancellous bone, numerous researches and analyses were performed [3]. Models were developed using CAD system (NX), later on simulations and analyses using FEM and CAE - ANSYS Workbench was employed:

- the dental implant of jaw bone was designed and there were performed FEM analyses of tension distribution in the jaw bone during distraction, without bone cutting and with various ways of bone cutting (Fig. 1);

- various designs of connection between the dental impact's body and its foot were designed and its strength was FEM simulated and analysed; this connection shall resist the torque of $0.5 \mathrm{Nm}$, necessary for screwing the dental implant into the jaw bone or for its removal (Fig. 2);

- strength of the mounting screw was analysed; for needs of FEM calculations, force of $608 \mathrm{~N}$ was used (registered for the premolar teeth).
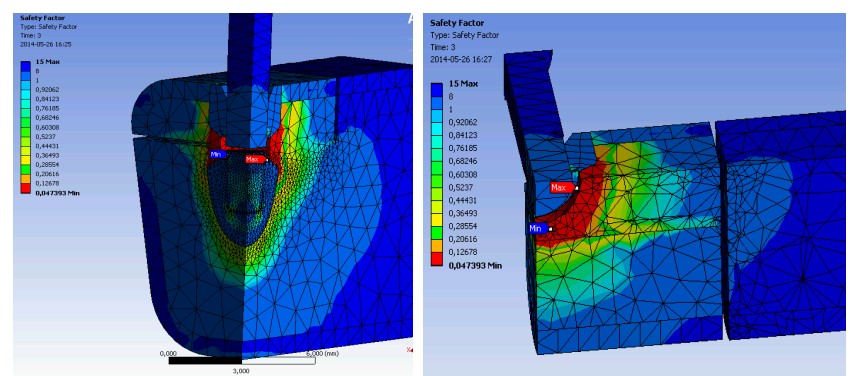

Fig. 1. Tension distribution when bone is cut

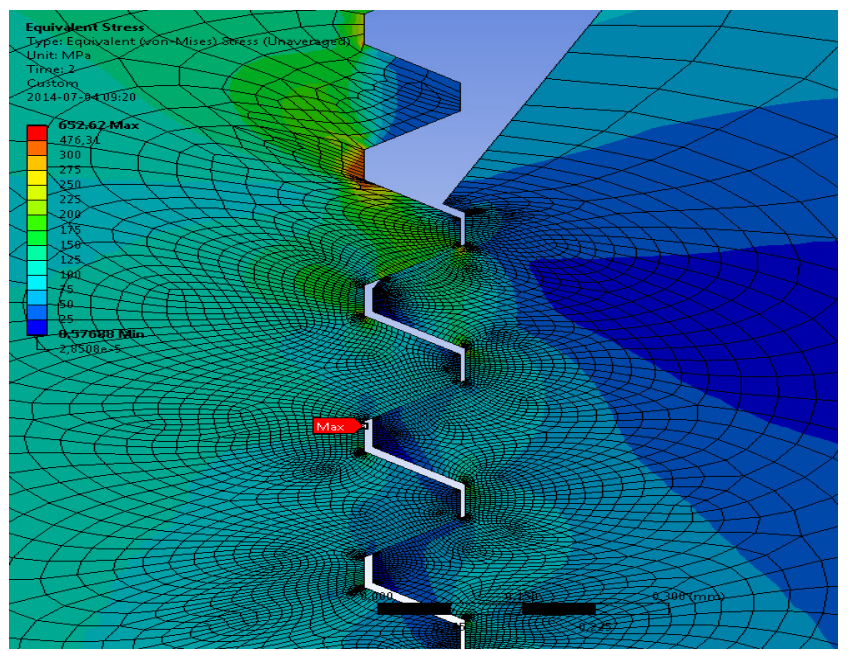

Fig. 2. Tension distribution in the dental implant thread 


\section{Methods and materials}

Developed dental implants were manufactured using the Selective Laser Sintering/Melting (SLS/SLM) technology. All of the implants components were built of the commercial Ti6Al4V powder using the Renishaw AM 250 machine (Fig. 3).
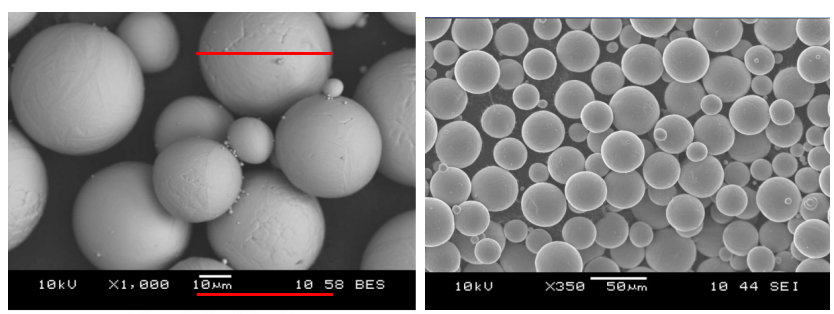

Fig. 3. Ti6Al4V powder SEM

Due to the limitations of the SLS/SLM technology, especially concerning the laser spot size $(100 \mu \mathrm{m})$ and size of the powder grain $(\sim 50 \mu \mathrm{m})$ it is necessary that the minimal dimension of the manufactured component should not be less than $0.1 \div 0.15 \mathrm{~mm}$. In case of smaller dimensions, the built structure might be discontinuous.

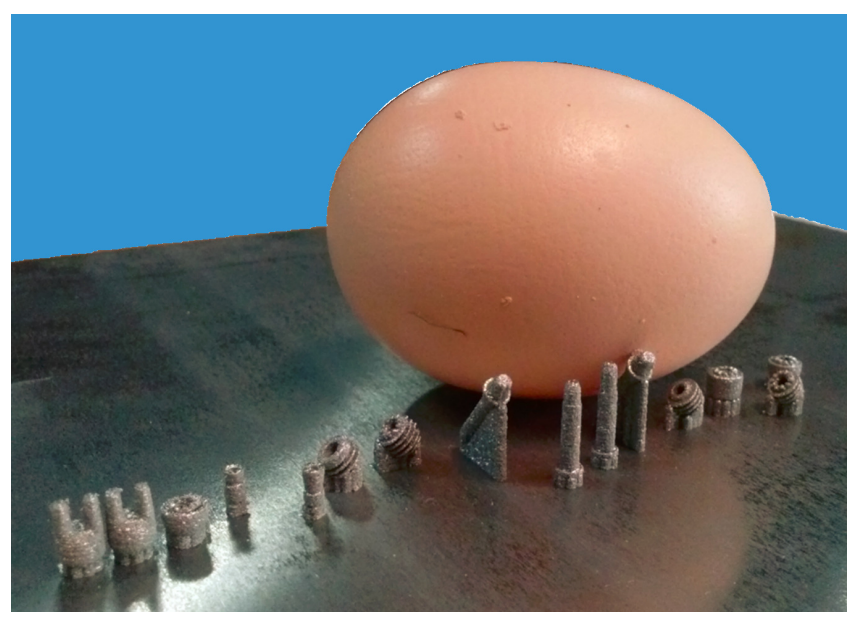

Fig. 4. Implanto-distractors manufactured using the SLS/SLM

Manufactured implanto-distractors are of size of $3 \div 15 \mathrm{~mm}$. The measured roughness (expressed in Ra coefficient) of their surfaces is around $50 \mu \mathrm{m}$. This parameter implies necessity of application of additional finishing machining operations (Fig. 4, 5).

\section{Results}

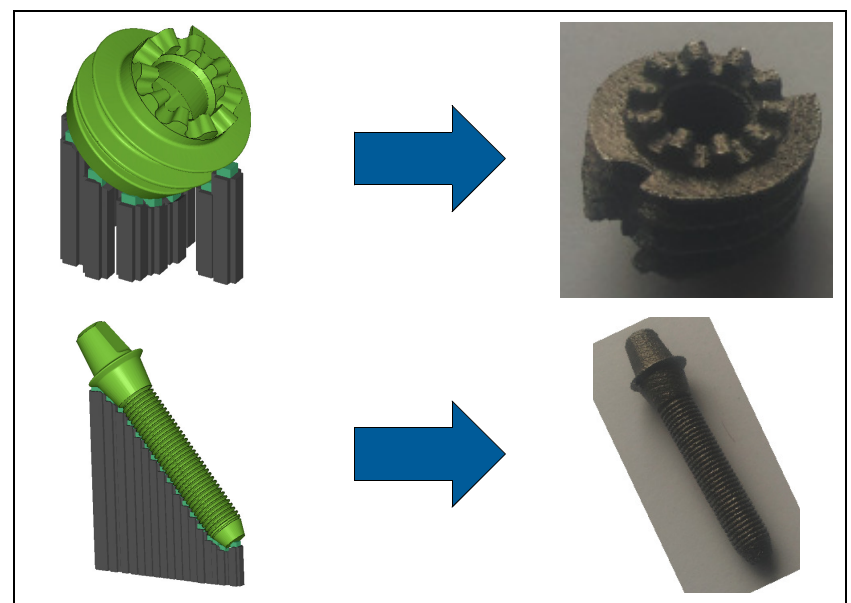

Fig. 5. Implanto-distractors manufactured with SLS/SLM technology - with additional supporting structures and final products
The presented in Fig. 6 tension distribution shows the impact of the ring's diameter of cancellous bone around the implant and the rounding diameter of the thread tip on the optimal shape of the thread. It is worth to mention that collected data might be stochastic and the same it can not be generalized. Uncertainty of the collected data on one hand might result of the complexity of surface describing the optimization function, whilst on the other it might also result from choice of optimization method or its parameters.

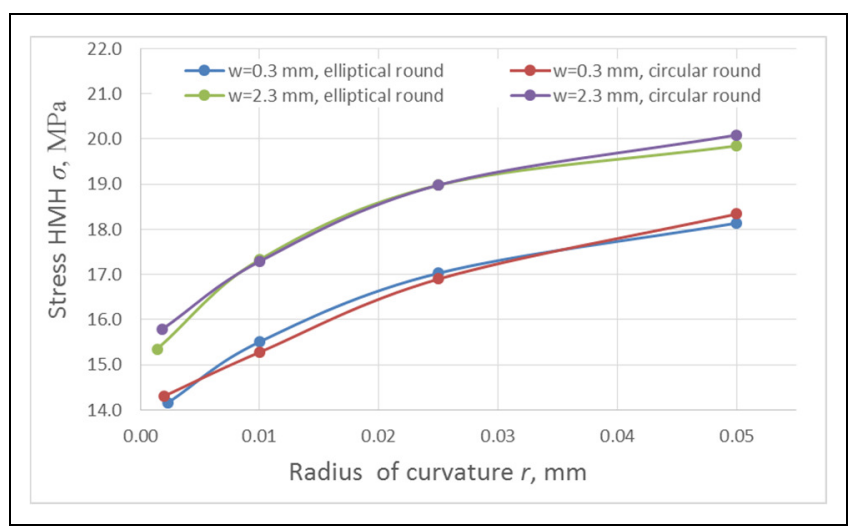

Fig. 6. Influence of the implant's tip radius on the $\mathrm{HMH}$ tensions in the cancellous bone

\section{Conclusions}

Presented way of optimization of the dental implant's thread allowed to perform the successful and effective optimization process. It occurred that application only of the axial load of dental implant leads to achieving optimal thread shape with sharp tip (tip rounding of $1 \mu \mathrm{m}$ ). However, the shape of thread is optimal, thread of this parameters is impossible to manufacture. It would be also harmful for the surrounding cancellous bone, due to tension distribution when the horizontal load on the implant appears there. Due to these facts, the minimal tip rounding shall be determined according to other criteria than used in the optimization.

When analysing the results of performer optimization, it is necessary to keep in mind the assumptions that were used for calculations. Optimal threads of the dental implant shall be verified with $3 \mathrm{D}$ models and additional experiments and research works.

Important aspect of performer works concerns manufacturing of the dental implant. Parts of bigger dimensions (with important details not smaller than $1 \mathrm{~mm}$ ) can be effectively produced with the additive manufacturing technologies, however it would be beneficial to use small grain powder (with grain size of $20 \mu \mathrm{m}$ ).

The work was supported under the Contract No. PBS2/A6/18/2014 (project title: „Development of manufacturing technology for implant-distracts") by The National Centre for Research and Development.

\section{LITERATURE}

1. Barão V.A., Delben J.A., Lima J., Cabral T., Assunção W.G. "Comparison of different designs of implant-retained overdentures and fixed full-arch implant-supported prosthesis on stress distribution in edentulous mandible - A computed tomography-based three-dimensional finite element analysis". Journal of Biomechanics. Vol. 46, No. 7 (2013): pp. 1312 $\div 1320$.

2. Eraslan O., Inan Ö. „The effect of thread design on stress distribution in a solid screw implant: a 3D finite element analysis".

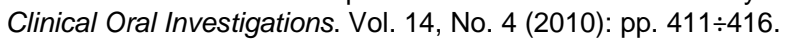

3. Machynia Z. „Optymalizacja zarysu gwintu implantu dentystycznego". Mechanik. R. 88, nr 4 (2015): s. 304:308. (Biuletyn IZTW) (DOI: http://dx.doi.org/10.17814/mechanik.2015.4.155). 